\title{
Way to longevity: role of antioxidant defense gene polymorphisms in successful adaptation
}

\author{
Vera Erdman \\ IBG UFRC RAS, Ufa, Russia \\ danivera@mail.ru \\ Ksenia Danilko \\ BSMU, Ufa, Russia \\ kse-danilko@yandex.ru
}

\author{
Timur Nasibullin \\ IBG UFRC RAS, Ufa, Russia \\ nasibullintr@yandex.ru \\ Olga Mustafina \\ IBG UFRC RAS, Ufa, Russia \\ anmareg@mail.ru \\ Alisa Matua \\ SRI EPT ASA, Sukhum, Abkhazia \\ azmatua@mail.ru
}

\author{
Ilsia Tuktarova \\ IBG UFRC RAS, Ufa, Russia \\ iltuk@mail.ru \\ Tatiana Viktorova \\ BSMU, Ufa, Russia \\ t_vict@mail.ru
}

\begin{abstract}
We carried out the analysis of associations between polymorphic loci of antioxidant defense genes with ethnicity and longevity. We found the interethnic differences in the distribution of allele frequencies of SOD1, SOD2, CAT, NQO1 genes. For reaching longevity $S O D 1, S O D 2, N Q O 1$, GPX1 genes were significant among Russians, SOD2, CAT genes among Tatars, MSRA, CAT genes - among Bashkirs.
\end{abstract}

Keywords - human longevity, adaptation, antioxidant defense, associative analysis, genetic polymorphism

\section{Motivation and aim}

\section{Motivation}

Longevity is a complex phenomenon of surviving to an age significantly exceeding the average species lifespan. Among possible causes of aging and longevity about 25\% are genetic and $25 \%$ are external factors, while the majority about $50 \%$ - is the way of carry out the interaction of exogenous and endogenous factors. To date, the question remains as to which particular combinations of factors of hereditary and environmental nature contribute to achieving the age of longevity. An organism is an open system, therefore it is precisely those external agents (molecules, substances, ions) that primarily come into contact with it deserve special attention. First of all, it is oxygen participating in the energy exchange inside the cell. Getting into the body, it enters a chain of chemical transformations. And already the metabolic products of those structures are involved in the adaptation process and regulate (modify) homeostasis [1]. The enzyme activity level is determined by the genetic variation in the structure of their genes. Thus, individual genotypic features determine the variability of the enzymatic antioxidant system, and, therefore, the plasticity of chemical and physiological reactions that determine the range of adaptive capabilities of the body.

Aim

The purpose of the study was the analysis of the polymorphic markers of some genes-candidate of aging and longevity, which relate to the body's defense system against oxidative stress, considering ethnicity, age gradation and gender differentiation.

\section{Methods}

Total group (3664 people) included individuals living in the Republic of Bashkortostan and belonging to three ethnic groups - Russians, Bashkirs and Tatars and in age from 1 to 109 years old. The biological material was DNA isolated from
$8 \mathrm{~mL}$ of whole venous blood by standard phenol-chloroform extraction. Allelic variants of the genes were identified by RTPCR using TaqMan probes. For statistical analysis of the results of the study, computer programs SPSS (v.13.0), GENEPOP, and Arlequin (v.3.0) were used.

\section{Results}

We found interethnic differences in the distribution of allele frequencies of superoxidedismutases 1 and $2(\mathrm{Mn}, \mathrm{Cu}-$ SOD and Mn-SOD), catalase (CAT), NAD(P)H Quinone dehydrogenase 1 (NQO1) genes. To reach the age of longevity, genotypes $S O D 1 * \mathrm{~A} / \mathrm{A}, S O D 1 * \mathrm{~A} / \mathrm{G}, S O D 2 * \mathrm{~A} / \mathrm{A}$, $N Q O 1{ }^{*} \mathrm{C} / \mathrm{T}, N Q O 1{ }^{*} \mathrm{C} / \mathrm{C}$ and $G P X 1 * \mathrm{~L} / \mathrm{L}$ were significant among Russians, genotypes SOD2*A/A, SOD2*V/V, $S O D 2 * \mathrm{~V} / \mathrm{A}, C A T^{*} \mathrm{C} / \mathrm{T}, C A T^{*} \mathrm{C} / \mathrm{C}$ were significant among Tatars, genotypes $M S R A^{*} \mathrm{C} / \mathrm{C}, C A T^{*} \mathrm{C} / \mathrm{C}$ were significant among Bashkirs. Based on modern ideas about the genes of aging and longevity, antioxidant defense genes related to "frailty genes" [2]. A number of associative studies have shown the participation of antioxidant defense genes in the development of multifactorial and age-associated diseases that limit the lifespan [3-5]. However, genetically determined functioning of the antioxidant defense enzyme system can become the key to the molecular base for the formation of an individual phenotype of longevity.

\section{ACKNOWLEDGMENT}

The study was carried out according the state task (State Registration No. AAAA-A16-116020350032-1) in part and funded by RFBR and ASA according to the research project \# 19-54-40007.

\section{REFERENCES}

[1] Novikov V.E., Levchenkova O.S., Pozhilova E.V. (2014) The role of reactive oxygen species in the physiology and pathology of the cell and their pharmacological regulation. Reviews on clinical pharmacology and drug therapy. 12(4): 13-21.

[2] Ukraintseva S. et al. (2016) Puzzling role of genetic risk factors in human longevity:"risk alleles" as pro-longevity variants. Biogerontology. 17(1): 109-127.

[3] Vorobyova E.N., Vorobyev R.I. (2005) The role of free radical oxidation in the pathogenesis of diseases of the circulatory system. Siberian Scientific Medical Journal. 4: 24-30.

[4] Soerensen M. et al. (2012) Human longevity and variation in GH/IGF1/insulin signaling, DNA damage signaling and repair and pro/antioxidant pathway genes: cross sectional and longitudinal studies. Experimental gerontology. 47(5): 379-387.

[5] Levy D., Reichert C.O., Bydlowski S.P. (2019) Paraoxonases activities and polymorphisms in elderly and old-age diseases: An overview. Antioxidants. 8(5): 118-142. 